\title{
Erratum to: 'Updated prevalence rates of overweight and obesity in 11- to 17-year- old adolescents in Germany. Results from the telephone-based KiGGS Wave 1 after correction for bias in self-reports'
}

Anna-Kristin Brettschneider ${ }^{1 *}$, Angelika Schaffrath Rosario ${ }^{1}$, Ronny Kuhnert ${ }^{1}$, Steffen Schmidt ${ }^{2}$, Susanna Wiegand ${ }^{3}$, Ute Ellert ${ }^{1 \dagger}$ and Bärbel-Maria Kurth ${ }^{1 \dagger}$

Unfortunately, the original version of this article [1] contained an error. The spelling of the author [Anna-Kristin Brettschneidera] name was incorrect. This has been corrected above and also included correctly below:

Anna-Kristin Brettschneider

\begin{abstract}
Author details
'Department of Epidemiology and Health Monitoring, Robert Koch Institute, General-Pape-Str. 62-66, 12101 Berlin, Germany. ${ }^{2}$ Department of Sports and Sports Science, Karlsruhe Institute of Technology, Engler-Bunte-Ring 15, 76131 Karlsruhe, Germany. ${ }^{3}$ Department of Pediatric Endocrinology and Diabetology, Charité Universitätsmedizin Berlin, Augustenburger Platz 1, 13353 Berlin, Germany.
\end{abstract}

Published online: 09 March 2016

\section{Reference}

1. Brettschneidera AK, Rosario AS, Kuhnert R. Updated prevalence rates of overweight and obesity in 11- to 17-year-old adolescents in Germany. Results from the telephone-based KiGGS Wave 1 after correction for bias in self-reports. 2015;15:1101

\footnotetext{
* Correspondence: BrettschneiderA@rki.de

${ }^{\dagger}$ Equal contributors

'Department of Epidemiology and Health Monitoring, Robert Koch Institute, General-Pape-Str. 62-66, 12101 Berlin, Germany

Full list of author information is available at the end of the article
}

Submit your next manuscript to BioMed Central and we will help you at every step:

- We accept pre-submission inquiries

- Our selector tool helps you to find the most relevant journal

- We provide round the clock customer support

- Convenient online submission

- Thorough peer review

- Inclusion in PubMed and all major indexing services

- Maximum visibility for your research

Submit your manuscript at

www.biomedcentral.com/submit

\section{C) Biomed Central}

